\title{
Implementing ERP Systems Globally: Challenges and Lessons Learned for Asian Countries
}

\author{
Paul Hawking \\ Victoria University, Australia
}

\begin{abstract}
Improved communication technology has seen growth in a convergence of global corporate activities. In an effort to improve their global operations many companies are implementing global information systems in particular Enterprise Resource Planning (ERP) systems. Companies are faced with a number of complexities when implementing these systems in a single country and considerable research has been conducted on the critical success factors associated with ERP implementations. However very little research has been conducted on the issues associated with global implementations of ERP systems and in particular implementations within the Asian region. This research utilises industry presentations to identify challenges and best practice for global implementations from the Asian region. The challenges have been classified as either technological or cultural pertaining to particular countries. The identified factors provide a foundation for further investigation.
\end{abstract}

\section{Keywords}

Enterprise Resource Planning systems, global implementation, Asian region.

\section{Introduction}

There has been significant growth in international corporate operations. For most companies this has been to take advantage of new opportunities or to leverage existing operations. While there is no "golden rule" as to how these international operations should be implemented or managed, Michael Porter (1986) in his book "Competition in Global Industries" classifies the various global strategies adopted by different corporations along a continuum from multi-domestics through to multi-nationals. According to Porter (1986) multi-domestics refers to offshore operations operating independently and are based upon local business processes supported by a local infrastructure. At the other end of the continuum are multi-nationals; where operations are integrated globally, based on standardised business processes with the ability to account for local differences. Bartlett and Ghoshi (1998) also identified a continuum consisting of four strategies which could be employed to support global operations. These strategies are multinational, international, global and transnationals. The continuum reflects increasing levels of integration and control between the various global strategies. At one end of the continuum are multinationals which by definition are similar to Porter's (1986) "multi-domestics". The authors argue that this strategy provides flexibility to

Copyright (C) 2007 Victoria University. This document has been published as part of the Journal of Business Systems, Governance and Ethics in both online and print formats. Educational and non-profit institutions are granted a nonexclusive licence to utilise this document in whole or in part for personal or classroom use without fee, provided that correct attribution and citation are made and this copyright statement is reproduced. Any other usage is prohibited without the express permission of the respond to domestic opportunities. While the international strategy allows subsidiaries a level of autonomy it also provides for the diffusion of the parent company's knowledge and practices throughout the organisation. In a global strategy there is centralised coordination and control involving standardisation of all aspects of the value chain. Transnationals 
are the final strategy in the continuum and support standardisation and a high level of integration across the organisation, while at the same time achieving the balance between flexibility and sensitivity to local needs.

\section{Global Information Systems}

Underpinning the level of integration and control in each of these strategies is the role of information systems (IS). This is supported by many authors who believe that a catalyst for global operations has been the improvement in the IS and technological infrastructure that supports the systems (Markus et al. 2001; Ives and Jarvenpaa, 1991; Konsynski and Karimi, 1993). Barlett and Ghoshai (1998) argue that companies operating in a global market will be at a strategic disadvantage if they are unable to control and coordinate their world wide operations.

The basic purpose of an information system is the provision of information to support decision making. Accordingly the improved flow of information provides companies with the ability to better coordinate and manage their operations while at the same time providing increased visibility to their global supply chain (Sheu et al., 2003). Traditionally this flow of information has been hindered due to a number of factors including: technological infrastructure, poor and disparate systems and lack of standardisation. Most international companies operated in a relatively autonomous nature from country to country and the supporting IS was managed and developed in a similar way. However a number of authors argue that it is critical for global operations to have a centrally managed and coordinated IT infrastructure (Freeman, 1985; Carlyle, 1990). Accordingly companies developing IT strategies to facilitate their global operations has resulted in the emergence of global information technology solutions.

Ives and Jarvenpaa (1991) define these types of applications as information systems that:

- Contribute to achieving a firm's global business strategy

- Utilise information technology platforms to store, transmit and manipulate data across cultural environments.

They went further and identified a number of drivers for global IT applications. These include:

\section{- Global consumer/customer}

Corporate customers have operations in numerous locations or due to consumers' mobility, access to centralised systems is required. This would be relevant in airline, credit card and accommodation related companies.

- Global Product

The IT infrastructure supports the sales of the same product in numerous locations, or the products and/or their components are produced via subsidiaries across the world.

- Rationalised Operations

Subsidiaries are located to take advantage of local opportunities, where increased coordination and control is required.

- Flexible Operations

Due to local opportunities, operations are moved from location to location. This is facilitated by standardised IT infrastructure.

\section{- Joint Resources}

Shared services enable subsidiaries to standardise business practices and gain efficiencies through shared resources such as personnel and facilities.

- Duplicate Facilities

Companies duplicate facilities in different locations including the IS infrastructure, to standardise practices and improve coordination and control by management.

- Scarce Resources

IT infrastructure can facilitate the sharing of scarce resources and expertise across international boundaries. 
- Risk Reduction

Access to relevant information related to global operations in relation to supply chain management, currency conversion, global markets and business partners can alleviate possible risks.

- Legal Requirements

Legislated information requirements in one or more countries can be consolidated.

- Economies of scale for systems

Global IT infrastructure through the standardisation and consolidation of business processes can facilitate a reduction in IT systems and supporting personnel (Ives and Jarvenpaa, 1991).

Although the benefits of global expansion have been documented, researchers have identified a range of factors which impact on business in an international context and therefore should be strategically planned for. These include the impact of culture, language, customs, politics, management style, and legal requirements (Simchi-Levi et al., 2000; Hofstede, 1983). Accordingly if a global IT infrastructure is to be implemented, then these issues need to be understood in terms of their impact on this infrastructure. Cash (1988) identified a number of problems associated with global IS solutions such as, language, currency, culture, national infrastructure, availability of IT staff, data export control trade unions and IT vendors support.

\section{Enterprise Resource Planning Systems}

The predominant information system implemented to support the various business processes in large corporations is an Enterprise Resource Planning (ERP) system. ERP systems are information systems which are enterprise wide, modular, integrated and have broad business functionality (Hawking, 2005).

Due to the purported benefits of ERP systems, many companies consider them as essential information systems infrastructure to be competitive in today's business world and provide a foundation for future growth. A survey of 800 top US companies showed that ERP systems accounted for $43 \%$ of these company's application budgets (Somer \& Nelson, 2001). The market penetration of ERP systems varies considerably from industry to industry. A report by Computer Economics Inc. stated that $76 \%$ of manufacturers, $35 \%$ of insurance and health care companies, and $24 \%$ of Federal Government agencies already have an ERP system or are in the process of installing one (Stedman, 1999). The ARC Advisory Group (2006) estimated that the worldwide market for ERP systems was $\$ 16.67$ billion in 2005 and is forecasted to surpass \$21 billion in 2010.

Researchers believe the growth in the uptake of ERP systems is due to several factors; the need to streamline and improve business processes, better manage information systems expenditure, competitive pressures to become a low cost producer, increased responsiveness to customers and their needs, integrate business processes, provide a common platform and better data visibility, and as a strategic tool for the move towards electronic business (Davenport et al., 2003; Hammer, 1999; Iggulden, 1999; Somer et al., 2001; Markus et al., 2001).

Increasingly due to the integrative nature of ERP systems and their ability to incorporate "best business" practice many large corporations are using these systems to underpin their international expansion. The systems can facilitate the control and coordination of various international operations in real time. This coordination and control can occur through the implementation of standardised business practices, independent of location, language, time and currency (Bingi et al., 1999; Madapusi and D'Souza, 2005). Texas instruments with 13,000 users worldwide, 45,000 products and 120,000 orders per month implemented an ERP system to support their operations. The system enabled the company to standardise business processes, leverage supply chain efficiencies and achieve a response time of less than 3 seconds (Sarkis and Sundarraj, 2003). In the Australasian region companies like BHP Billiton, Fonterra, Monash University, Carter Holt Harvey, Bluescope Steel and National Australia Bank are using ERP systems to support their global operations. 
For many companies underestimating the impact the system would have on their organisation, caused them to initially struggle with their ERP implementation. For some the barriers associated with the lack of skilled resources and inexperience with projects of this scope became insurmountable (Calegero, 2000). Davenport (2000) believes that ERP systems by their very nature impact on a company's business strategy, organisation and culture. The move to become process rather than functionally focused and the resultant need for business process integration can result in a loss in competitive advantage in particular areas. However the potential benefits across the entire organisation often outweighs the losses in individual areas (Holland and Light, 2001). Many researchers have attempted to identify the critical success factors (CSF) which impact on the successful implementation of an ERP system (Table 1).

\begin{tabular}{|c|c|c|}
\hline Critical Success Factor & Components & Researchers \\
\hline Organisational fit & $\begin{array}{l}\text { Failure to re-design business processes } \\
\text { Failure to follow an enterprise-wide } \\
\text { design which supports data } \\
\text { integration } \\
\text { Lack of data integration and lack of } \\
\text { data standardisation }\end{array}$ & $\begin{array}{l}\text { Holland and Light, } 1999 \\
\text { Shanks et al., } 2000 \\
\text { Sumner, } 1999 \\
\text { Summer, } 2000 \\
\text { Esteves, Casanovas, and Pastor, } 2003\end{array}$ \\
\hline Skill mix & $\begin{array}{l}\text { Insufficient training and re-skilling } \\
\text { Insufficient internal expertise } \\
\text { Lack of business analysts with business } \\
\text { and technology knowledge } \\
\text { Failure to effectively mix internal and } \\
\text { external expertise } \\
\text { Lack of ability to recruit and retain } \\
\text { qualified ERP systems developers }\end{array}$ & $\begin{array}{l}\text { Holland and Light, } 1999 \\
\text { Sumner, } 1999 \\
\text { Summer, } 2000 \\
\text { Shanks et al., } 2000 \\
\text { Esteves, Casanovas, and Pastor, } 2003\end{array}$ \\
\hline $\begin{array}{l}\text { Management structure } \\
\text { and strategy }\end{array}$ & $\begin{array}{l}\text { Lack of senior management support } \\
\text { Lack of proper management control } \\
\text { structure } \\
\text { Lack of a champion } \\
\text { Ineffective communications } \\
\text { Lack of a change management strategy }\end{array}$ & $\begin{array}{l}\text { Holland and Light, } 1999 \\
\text { Sumner, } 1999 \\
\text { Summer, } 2000 \\
\text { Shanks et al., } 2000 \\
\text { Allen and Kern, 2001 } \\
\text { Esteves, Casanovas, and Pastor, } 2003\end{array}$ \\
\hline Software systems design & $\begin{array}{l}\text { Failure to adhere to standardised } \\
\text { specifications which the software } \\
\text { supports } \\
\text { Failure to effectively integrate "add- } \\
\text { on" modules } \\
\text { Failure to recognise the importance of } \\
\text { application-specific knowledge }\end{array}$ & $\begin{array}{l}\text { Holland and Light, } 1999 \\
\text { Summer, } 2000 \\
\text { Allen, Kern and Havenhand, } 2002 \\
\text { Esteves, Casanovas,and Pastor, } 2003\end{array}$ \\
\hline $\begin{array}{l}\text { User involvement and } \\
\text { training }\end{array}$ & $\begin{array}{l}\text { Insufficient training of end-users } \\
\text { Ineffective communications } \\
\text { Lack of full-time commitment of } \\
\text { customers to project management and } \\
\text { project activities } \\
\text { Lack of sensitivity to user resistance } \\
\text { Failure to emphasise reporting }\end{array}$ & $\begin{array}{l}\text { Holland and Light, } 1999 \\
\text { Shanks et al., } 2000 \\
\text { Sumner, } 1999 \\
\text { Summer, } 2000 \\
\text { Allen and Kern, } 2001 \\
\text { Allen, Kern and Havenhand, } 2002 \\
\text { Esteves, Casanovas,and Pastor, } 2003\end{array}$ \\
\hline Technology planning & $\begin{array}{l}\text { Inability to avoid technological } \\
\text { bottlenecks } \\
\text { Lack of an integrated technology } \\
\text { strategy to support client-server } \\
\text { implementation } \\
\text { Attempting to build bridges to legacy } \\
\text { applications }\end{array}$ & $\begin{array}{l}\text { Holland and Light, } 1999 \\
\text { Summer, } 2000 \\
\text { Esteves, Casanovas,and Pastor, } 2003\end{array}$ \\
\hline Project management & $\begin{array}{l}\text { Lack of disciplined, flexible project } \\
\text { management }\end{array}$ & $\begin{array}{l}\text { Holland and Light, } 1999 \\
\text { Sumner, } 1999\end{array}$ \\
\hline
\end{tabular}


Failure to recognise the risk of scope expansion (time, cost)
Shanks et al., 2000

Summer, 2000

Esteves, Casanovas,and Pastor, 2003

Table 1: Critical Success Factors for ERP implementations

\section{Challenges in Global ERP Implementations}

Although the potential benefits of global ERP systems implementation have been documented these types of implementations are faced with a number of issues. The critical success factors of ERP implementations identified previously in the paper are predominantly based on research on a particular ERP system in a particular country. Very little research discusses the relevance of these factors in global implementations and obviously there is a need to validate these. A number of authors rather than identifying CSFs in global implementations have identified what could be termed as "challenges" or "lesson learnt". A major issue is the impact of national culture. ERP vendors encourage the use of global templates to facilitate the implementations. The global template incorporates standardised definitions of organisational structures, master data and business processes. However much of the literature argues against the extensive use of global templates due to the lack of flexibility at the local level to take advantages of regional opportunities and to account for cultural differences (Hanseth et al., 2001; Liang et al., 2004). But global templates are being increasingly adopted by large companies to improve the information flow due to the standardisation.

Krumbholz et al. (2000) investigated cultural differences between a large pharmaceuticals company's operations in the United Kingdom and Scandinavia. They found differences in how the ERP system should be implemented to take into account different legislative requirements in each country; they did not find any significant cultural differences. However other researchers (van Everingdon and Waarts, 2003) using Hofstede's (1983) model of cultural differences studied the adoption of innovation, in particular ERP systems, across different European cultures. It was found that national culture does impact on the adoption of ERP systems and more specifically that there would be a negative impact in countries with higher levels of uncertainty avoidance, masculinity, and power distance.

Some authors argue that these cultural differences are further exacerbated when comparisons are made between eastern and western countries (Martinsons, 2004; Huang and Palvia, 2000). Liang et al. (2004) go further and addresses the applicability of western designed ERP systems to China. They argue that these systems are based on "rule based" mature economies rather than relation based governance systems like China. However the leading ERP system, developed by a German company (SAP), accounts for approximately 33\% of the China ERP market (Martinsons, 2004) and has had a 95\% increase in sales over a 12 month period (McBride, 2004). Sheu et al. (2003) noted there was confusion between western and eastern name formats. It was not the inability of the system to cope with the formats but rather a lack of understanding about the format itself. Wu and Wang (2002) compared the implementation of locally developed ERP systems to foreign developed ERP systems in Taiwan and the impact on user satisfaction. As would be expected, they found significantly higher satisfaction for the local system as it reflected the local user preferences. Davison (2002) supports this divide between east and west by arguing that the majority of ERP vendors are western and are therefore unlikely to support various aspects of eastern culture. By using simplistic examples he supports his argument; such as the automatic allocation of numbers by the system which may be offensive homonyms. Also, the majority of reports in ERP systems tend to be online while Asian workers prefer paper based reports.

Increasingly western based global companies have implemented their ERP system in the Americas and Europe and are now faced with rolling out their systems into the Asian region. A number of authors have discussed issues related to the implementation of ERP systems into an Asian country but limited research has identified issues associated with implementations as part of a global rollout. The issues identified thus far with conducting this type of research using traditional methods are numerous and include geographic, financial, language and cultural issues. This paper identifies the outcomes of research in the first phase of a four phased research approach into global ERP implementation issues. The purpose of this research was to identify global implementation issues in the Asian region. 


\section{Research Methodology}

A phased approach was adopted for gathering data concerning global ERP implementation issues. The first phase of the research adopts a semiotic approach involving content analysis. Krippendorf (1980) defines content analysis as "a research technique for making replicable and valid references from data to their contexts".

This data was collected from industry presentations, which focused on global implementations obtained from ERP user group conferences both locally and internationally. Some of the presentations include full transcripts or voice recordings of the presenter. In total there were approximately 2,000 presentations.

These presentations provide a detailed firsthand account of industry experiences associated with global implementations. The speakers who are invited to speak at these events are usually management level industry specialists and are generally knowledgeable on the topic presented.

A four-step process was used in the analysis of the content. This approach has been used previously by Yang and Seddon (2004) and more recently in Calvert \& Seddon (2005) in the evaluation of content.

Step 1: involves the recording of company demographics including solutions implemented and their scope.

Step 2: involves the tabulation of key points as identified by each speaker in their presentation in terms of lessons learnt, critical success factors, and or challenges specifically related to Asian country implementations.

Step 3: the speakers' comments are interpreted and coded including the grouping of similar factors.

Step 4: involves an independent researcher to independently interpret, code and group similar factors. The two groupings are then compared and refined.

\section{Findings}

Industry presentations were viewed and assessed from the American SAP User Group (AUSG) Conferences and Industry Forums (2003-2006) and the SAP Australian User Group (SAUG) events (2003-2006). These presentations were then reduced to those that were only concerned with global implementations and then to those that specifically mentioned their implementation into Asia or more specifically an Asian country. The table below (Table 2) provides an indication to the sample size.

\begin{tabular}{|l|l|l|l|l|}
\hline Conference & Presentations & Global & Global Asia & Lessons/Challenges \\
\hline ASUG & 2543 & 213 & 23 & 5 \\
\hline SAUG & 312 & 3 & 1 & 0 \\
\hline
\end{tabular}

Table 2: Presentation sample size

SAP User Group conferences were selected in comparison to other ERP vendor conferences as SAP is the leading ERP vendor with approximately $56 \%$ of the world market including $75 \%$ of the Asian market (McBride, 2005). An analysis of the presentations revealed that the implementation issues could be categorised into either technical or cultural. It would be expected that the cultural issues would apply to all ERP vendors while the technical issues could be product specific. A summary of findings is included in the appendix.

Although many of the presentations commented on Asian countries in general, a number of presentations indicated that it is a mistake to consider Asia as a single entity as issues vary from country to country (Woof, 2005; Woof; 2006; Paluszek, 2006).

The major issues were identified as being language, culture and currency. 


\section{Language}

For many of the implementations language was a major issue. This was identified from both a technical and cultural perspective. From a technical perspective, early SAP versions were not Unicode compliant. Unicode can be explained as a standard that allows each character of a language to be represented in a standard format. This facilitates the handling of different languages. Many of the companies attempted translations but this provided another level of complexity due to cultural issues which needed to be reflected in the system. For example Air Products (Paluszek, 2006) in their implementation of human resources functionality found that naming conventions varied from country to country. It was necessary to distinguish between a person's legal name and their "known as" name. In Indonesia employees tended to have only one name while in Korea titles were very important.

\section{Culture}

From a cultural perspective language and meaning were identified in a number of presentations as an issue (Paluszek, 2006; Woof, 2006, Hubert, 2005). This was in regard to understanding requirements and the unwillingness to seek clarification. This was reflected in staff saying 'Yes' without really understanding or agreeing positively. It was suggested that project managers need to reaffirm meaning and check employee progress more often.

In terms of written English one presenter indicated that emails should be short and concise as longer emails tend to be deleted before they are read. Additionally there is not the same willingness as western culture to respond to an email (Paluszek, 2006).

\section{Currency}

In terms of the different currencies, a common theme from the presentations was the representation of financial amounts within the system. SAP uses the ISO standard format which includes decimal places while many of the Asian currencies do not utilise this format. Additionally the currencies often involve very large numbers. For example annual salaries in different Asian countries might be:

- Korea: 300,000,000 Won

- Indonesia: $175,000,000$ Rupiah

- Japan: 250,000,000 Yen

All presentations indicated that there were some localisation issues including tax requirements, document handling and master data storage but none indicated that the project could not be implemented due these factors.

SAP in an attempt to facilitate the global implementation of their products and thus increase licence revenue have adopted a number of strategies. From a solution perspective the products are continually refined to take into account local requirements. This is especially the case in relation to human resource/payroll functionality. As changes occur in local requirements development requests are submitted to SAP by key customers as to the required solution changes. These changes usually occur in the next version release unless it impacts on all customers in the location.

To assist in the implementation SAP has included in its standard implementation methodology (ASAP) a component specifically designed for global roll outs. It would be interesting to evaluate this methodology in regards to the specific recommendations for different Asian countries. Additionally SAP has established a globalisation web site which includes country specific advice and a knowledge base.

It is interesting to note that all the presentations dealt with implementation issues rather than use issues. Maybe this is a reflection of the immaturity of the implementations in the Asian region with the emphasis on getting it working rather than enhancing the solutions operation. 


\section{Limitations of the Research}

This research is limited by the size of the sample. However based on the significant number of presentations which mentioned global implementations (216) only $11 \%$ mentioned the Asian region. This may indicate that there is going to be an increased number of implementations in the region or that other companies did not consider Asian implementations an issue. Other limitations are associated with the presentations themselves. Firstly presenters supply an abstract to conference organisers for acceptance. It is unlikely that a company will want to talk about significant failures to their peers in terms of protecting corporate reputations. However from the other end of the spectrum, companies with innovative solutions could be reluctant to present in case of divulging a competitive advantage. The sample taken from SAP based conferences is also a challenging limitation. However it is argued that SAP is a major player in the ERP software arena and as such it could be argued that using SAP as a base is valid.

\section{Conclusion}

ERP systems have become an essential infrastructure for many of the world's leading companies. The systems provide an increased level of integration to support core business processes. The provision of real time data facilities improved decision making. The improved integration and standardisation have made the systems attractive to companies to support their global operations. However the implementation and use of ERP systems face a number of issues due to their complexity and the impact they have on companies. These issues are further exacerbated in global environments where national cultures and local requirements come into play. Companies often have to achieve a balance between the level of standardisation and local requirements. Very little research has been undertaken which investigates the impact of different cultures on ERP systems implementation especially within the Asian region. This paper has collated industry presentations to identify possible issues in this region related to ERP systems. The issues have been classified as technological or cultural.

This research is far from comprehensive however it provides a starting point in an area of research which was virtually non existent. It provides future researchers with a foundation to expand upon.

\section{References}

Allen, D. and T. Kern, (2001); Enterprise Resource Planning Implementation: Stories of Power, Politics, and Resistance. IFIP Working Group: Realigning Research and Practice in Information Systems Development: The Social and Organizational Perspective, Idaho.

Allen, D., Kern, T., Havenhand, M., (2002) "ERP Critical Success Factors: An Exploration of the Contextual Factors in Public Sector Institutions" proceedings of the HICSS conference, Hawaii.

ARC Advisory Group (2006), "ERP Market to Exceed \$21 Billion, Says ARC Advisory" located at http://www.tekrati.com/research/News.asp?id=6828, accessed October 2006.

Bagwe, P. (2006), "Leveraging Global Delivery model for global roll-outs" proceedings of the 2006 ASUG Conference, Orlando.

Bartlett, C. A., Ghoshai, S.,1998; Managing Across Borders: The Transnational Solution, Harvard Business School Press, Boston.

Bingi, P., Sharma, M., Godla, J.,1999, “Critical Issues Affecting an ERP Implementation”, Information Systems Management, Summer.

Broadbent, M. and P. Weill,1993; "Improving Business and Information Strategy Alignment: Learning from the Banking Industry",. IBM Systems Journal, Vol. 32, No.1, pp. 162-179.

Carlino, J.,1999; "AMR Research Unveils Report on Enterprise Application Spending and Penetration,”. Located at www.amrresearch.com/press/files/99823.asp Accessed July 2001

Carlyle, R. E.,,1990; “The Tomorrow Organisation”, Datamation, February.

Carton, F., Adam F., (2003) "Analysing the Impact of Enterprise Resource Planning Systems Roll-outs in Multi-National Companies" - Electronic Journal of Information Systems Evaluation Vol. 6, Iss. 2. 
Cash, J. L., McFarlan, F.W., and McKenny, J. L.,1988; Corporate Information Systems Management: The Issues Facing Senior Executives, Irwin, Homewood, IL,

Clemmons, S., Simon, S. J.,,2001, "Control and Coordination in Global ERP Configuration”, Business Process Management Journal, Vol. 7, No. 3.

Davenport, T., Harris, J. and Cantrell, S.,2003; “Enterprise Systems Revisited: The Director's Cut" Accenture

Deloitte. 1998; "ERPs second wave", Deloitte Consulting.

Esteves, J., Casanovas, J.,Pastor, J.,2003; "Modelling with Partial Least Squares Critical Success Factors Interrelationships in ERP Implementations", Ninth Americas Conference on Information Systems.

Freeman, D. H.,1985; “Managing Information Systems at the Multinational”, Infosystems, Vol. 32, No. 1, January

Fonterra A. 2004, About Fonterra, located at www.fonterra.com accessed October 2004

Fonterra B. 2004, JEDI Programme: Key Message Guidelines, Fonterra

Ghosh, S. 2002; "Challenges on a Global Implementation of ERP Software", Proceedings of Engineering Management Conference, IEMC '02. IEEE International,

Ghosh, S., Ghosh, S., 2003; "Global Implementation of ERP Software - Critical Factors on Upgrading Technical Infrastructure”, proceedings of Engineering Management Conference, 2003. IEMC '03 IEEE International.

Hammer, M.,1999. "How Process Enterprises Really Work”, Harvard Business Review, Nov./Dec. 1999.

Hanseth, O., Ciborra, C. U., Braa, K.,2001; "The Control Devolution: ERP and the side effects of globalisation", ACM Press, Vol. 32, No. 4.

He, X. 2004, "The ERP Challenge in China: A Resource Based Perspective", Information Systems Journal, Vol. 14.

Hegde, P., Hornaday, S., Van Bellinghen, F., (2006), “Hospira: Internationalization of Payroll, Local Solutions for a Global Company" proceedings of the 2006 ASUG Conference, Orlando

Hofstede, G., 1983, "The cultural relativity of organisational practices and theories", Journal of International Business Studies, Fall.

Holland, C., Light, B., (2001), "A stage maturity model for enterprise resource planning systems use", ACM SIGMIS Database, Vol. 32, Iss. 2

Holland, C. P., Light, B., \& Gibson, N.,1999; "A critical success factors model for enterprise resource planning implementation", Proceedings of the 7th European Conference on Information Systems, 1 , $273-297$.

Huang, Z., Palvia, P., 2001; "ERP implementation issues in advanced and developing countries", Business Process Management Journal, Vol. 7, No. 3.

Hubert, D. (2006) "Pass The Duck Tongues - 10 Years and 20 Countries in a Global Implementation", proceedings of the 2006 ASUG Conference, Orlando.

Iggulden, T. Editor, 1999. "Looking for Payback", MIS, June 1999

Ives, B., Jarvenpaa, S., (1991), "Applications of global information technology: key issues for management", MIS Quarterly, Vol. 15, Iss. 1

Kay, E. 1998, "Going Global with ERP”, EarthWeb, available at http://itmanagement.earthweb.com/erp/article.php/603341 accessed June 2004.

Klaus, Helmut, Rosemann, Michael, and Gable, Guy G. 2000; "What is ERP, Information Systems Frontiers", Vol. 2, No. 2, 141-162.

Koch, C. 2001; "Enterprise Resource Planning: Information Technology as a Steamroller for Management Politics", Journal of Organisational Change Management, Vol. 14, No. 1.

Konysynski, B. R., and Karimi, J. 1993, On the Design of Global Information Systems, Globalisation Technology and Competition, eds. Bradley, S. P., Hausman, J. A., Nolan, R. I., Harvard Business School Press, Boston.

Krippendorff, K. 1980 Content analysis : An introduction to its methodology. Sage Publications, Beverly Hills. 
Krumbholz, M Galliers, J Coulianos, N., (2000) “Implementing enterprise resource planning packages in different corporate and national cultures", Journal of Information Technology, Vol. 15, No. 4.

Liang, H., Xue, Y., Boulton, W., Byrd, T, (2004) "Why Western Vendors Don't Dominate China's ERP Market", Communications of the ACM, Vol. 47, No. 7.

Light, B. 1999, " Realising the potential of ERP systems: The strategic implications of implementing and ERP strategy: The case of Global petroleum", Electronic Markets, Vol. 9, No. 45.

Madapusi, A. and D. D’Souza, (2005). "Aligning ERP systems with international strategies." Information Systems Management, Vol 22, No. 1: 7 -17.

Markus, L., Petrie, D., Axline, S. (2001), "Bucking The Trends, What the Future May Hold For ERP Packages", in Shanks, Seddon and Willcocks, Eds.; Enterprise Systems: ERP, Implementation and Effectiveness, Cambridge University Press

Martinsons, M., (2004) "ERP in China: One package, two profiles", Communications of the. ACM, Vol. 47, No. 7.

McBride, G. 2004, “The Year in Review”, SAP Partner Kick Off, Sydney.

Pagell M., Sheu C. 2001, "Buyer Behaviour and the Performance of the Supply Chain: An International Exploration". International Journal of Production Research, Vol. 39, No. 13.

Paluszek, B. (2006) "Into Asia - A Cultural and Technological Adventure", proceedings of the 2006 ASUG Conference, Orlando.

Porter, M. E. 1986; Competition in Global Industries, Harvard Business School Press, Boston, MA

Reimers, K. 2003. "Implementing ERP systems in China." Communications of the Association for Information Systems 11.

Sahay, S. 2003, "Global Software Alliances: The Challenges of Standardisation", Scandinavian Journal of Information Systems, Vol. 15.

Sarkis, J., Sundarraj, R. P. 2003, "Managing large scale global Enterprise Resource Planning Systems: A Case Study at Texas Instruments", International Journal of Information Management, Vol. 23, No.5.

Scott Morton, M.S.,1991; 'The Corporation of the 1990s: Information Technology and Organizational Transformation' Oxford University Press, New York, 1991.

Seltsikas, P. 1999, "Developing information systems strategy for international process oriented holistic enterprises: A case study at Xerox Ltd.", Electronic Markets, Vol. 9, No. 45.

Shanks, G., Parr, A., Hu, B., Corbitt, B., Thanasankit, T., \& Seddon, P. 2000. "Differences in critical success factors in ERP systems implementation in Australia and China: Acultural analysis, Proceedings of the 8th European Conference on Information Systems, Vienna, Austria,

Sheu, C., Chae, B., Yang, C.-L. (2004) "National difference and ERP implementation: issues and Challenges," The International Journal of Management Science (32),

Simchi-Levi, D., Kaminsky, P., Simchi-Levi, E. 2000, Designing and Managing the Supply Chain: Concepts, Strategies and Case Studies, Irwin/McGraw Hill, Boston MA.

Soh, C., Kien, S., Tay-Yap, J. 2000; "Enterprise resource planning: cultural fits and misfits: is ERP a universal solution?" Communications of the ACM, Vol. 43, No 4,: 47-51.

Somer, T. and K. Nelson, 2001, "The impact of Critical Success Factors across the Stages of Enterprise Resource Planning Systems Implementations", proceedings of the $34^{\text {th }}$ Hawaii International Conference on System Sciences, 2001, HICSS

Stedman, C.,1999. "What's next for ERP?" Computerworld, 33(33; August 16

Sumner, M. 2000. "Risk factors in enterprise-wide/ERP projects.” Journal of Information Technology, Vol. 15, No.4: 317 - 327.

Sumner, M. 1999. "Critical success factors in enterprise wide information management systems Projects", Proceedings of the Americas Conference on Information Systems, Milwaukee, WI,

Teo, T. \& King, W., 1997, "Integration between business planning and information systems planning: an evolutionary contingency perspective", Journal of Management Information Systems No. 14,

Van Everdingen, Y., Waarts E., (2003), “A Multi-country Study of the Adoption of ERP Systems: The Effect of National Culture" located at http://ideas.repec.org/p/dgr/eureri/2003290.html\#provider accessed May 2005. 
Warren, M. 2002, "Global Implementation at BHP Billiton" presentation at the $18^{\text {th }}$ Plenary of the Australian SAP User Group, Sydney.

Wood, T. and Caldas, M. (2000) Stripping the "Big Brother": Unveiling the Backstage of the ERP Fad, located at http://www.gv.br/prof alunos/thomaz/ingles/paper5.htm accessed May 2005

Woof, R., (2006),"Managing a Global Template with local Requirements" proceedings of the 2006 ASUG Conference, Anaheim

Woof, R., (2006),'Implementing an SAP Global Template in Asia" proceedings of the 2006 ASUG Conference, Orlando

Yang, S. and P. Seddon (2004). "Benefits and Key Project Success Factors from Enterprise Systems Implementations: Lessons from Sapphire 2003". In the proceedings of ACIS 2004, Hobart, UTAS.

Zhang, L., M. Lee, et al., 2003. "Critical Success Factors of Enterprise Resource Planning Systems Implementation Success in China", proceedings $36^{\text {th }}$ Hawaii International Conference on System Sciences.

\section{Appendix}

\begin{tabular}{|c|c|c|c|c|}
\hline Company & $\begin{array}{c}\text { Scope of } \\
\text { Implementation } \\
\end{array}$ & Country & Issue & Category \\
\hline \multirow{3}{*}{$\begin{array}{l}\text { Hospira } \\
(13,000 \\
\text { employees) } \\
\text { (Hedge et al., } \\
2006)\end{array}$} & $\begin{array}{l}\text { Human } \\
\text { Resources, } \\
\text { Payroll }\end{array}$ & Japan & $\begin{array}{l}\text { Require to present in person applications } \\
\text { to the government for new employees }\end{array}$ & $\begin{array}{l}\text { Technical } \\
\text { Cultural }\end{array}$ \\
\hline & & Philippines & $\begin{array}{l}\text { Distribution of sack of rice as part of } \\
\text { wages }\end{array}$ & $\begin{array}{l}\text { Technical } \\
\text { Cultural }\end{array}$ \\
\hline & & Hong Kong & Avoid number 4 & $\begin{array}{l}\text { Technical } \\
\text { Cultural }\end{array}$ \\
\hline \multirow{6}{*}{$\begin{array}{l}\text { Wabco } \\
(7,000 \\
\text { employees) } \\
\text { (Bagwe, 2006) }\end{array}$} & $\begin{array}{l}\text { Majority of } \\
\text { modules (v. 4.7) }\end{array}$ & China & Golden tax interface & Technical \\
\hline & & & $\begin{array}{l}\text { Exchange rate interface with Bank of } \\
\text { China }\end{array}$ & Technical \\
\hline & & & Chinese characters in forms & Technical \\
\hline & & & Customer master data descriptions & Technical \\
\hline & & Korea & Chinese characters in forms & Technical \\
\hline & & & Customer master data descriptions & Technical \\
\hline \multirow[t]{4}{*}{$\begin{array}{l}\text { Molex } \\
(28,000 \\
\text { employees })\end{array}$} & $\begin{array}{l}\text { Majority of ERP } \\
\text { modules (v. 4.7) } \\
\text { CRM, APO, } \\
\text { BW, SRM }\end{array}$ & Japan & Japans and Kanji data & Technical \\
\hline & & & Special EDI requirements & Technical \\
\hline & & & Unique shipping documents & Technical \\
\hline & & India & $\begin{array}{l}\text { Sudden and last minute government } \\
\text { requirements }\end{array}$ & Technical \\
\hline \multirow{4}{*}{$\begin{array}{l}\text { BOC } \\
(53,000 \\
\text { employees) } \\
\text { (Woof, 2005; } \\
\text { Woof, 2006) }\end{array}$} & $\begin{array}{l}\text { All ERP modules } \\
\text { (v4.7), CRM, } \\
\text { APO, BW, SRM }\end{array}$ & Singapore & Persistent, detailed analytics & Cultural \\
\hline & & Hong Kong & $\begin{array}{l}\text { Both local and Chinese currency } \\
\text { requirements }\end{array}$ & Technical \\
\hline & & Japan & Japanese and Kanji data issues & Technical \\
\hline & & & $\begin{array}{l}\text { Unique EDI and shipping document } \\
\text { requirements }\end{array}$ & Technical \\
\hline
\end{tabular}




\begin{tabular}{|c|c|c|c|c|}
\hline & & China & Language translation issues & Technical \\
\hline & & & Golden Tax System & Technical \\
\hline & & & Long Bank account numbers & Technical \\
\hline & & & $\begin{array}{l}\text { Less English of staff but better quality of } \\
\text { English where existed }\end{array}$ & Cultural \\
\hline & & & $\begin{array}{l}\text { High staff turnover as staff move to } \\
\text { higher wages due to demand for SAP } \\
\text { skills }\end{array}$ & Cultural \\
\hline & & Korea & No decimal places in currency & Technical \\
\hline & & & More resistance to change & Cultural \\
\hline & & & $\begin{array}{l}\text { Business transactions tend to be without } \\
\text { paperwork }\end{array}$ & Cultural \\
\hline & & Thailand & Inter-company sales illegal & Technical \\
\hline & & & $\begin{array}{l}\text { Staff continually changed roles in } \\
\text { company which became a major issue in } \\
\text { training }\end{array}$ & Cultural \\
\hline & & & $\begin{array}{l}\text { More English speakers but speaking and } \\
\text { understanding a poorer quality }\end{array}$ & Cultural \\
\hline & & & $\begin{array}{l}\text { Eager to please but often "Yes" does not } \\
\text { mean "Yes" }\end{array}$ & Cultural \\
\hline & & Philippines & $\begin{array}{l}\text { "Eager to say 'Yes' - quick to say a task } \\
\text { had been done but required constant } \\
\text { checks to see it had actually been done" }\end{array}$ & Cultural \\
\hline \multirow[t]{2}{*}{$\begin{array}{l}\text { Air Products } \\
(20,000 \\
\text { employees) } \\
\text { (Paluszek, } \\
2006)\end{array}$} & $\begin{array}{l}\text { HR, Manager } \\
\text { Self Service }\end{array}$ & China & $\begin{array}{l}\text { Unable to handle employment contracts } \\
\text { where a person is employed by the } \\
\text { government but on loan to the company }\end{array}$ & Technical \\
\hline & & Taiwan & $\begin{array}{l}\text { Addresses can only be entered in } \\
\text { Chinese }\end{array}$ & Technical \\
\hline
\end{tabular}

CRM (Customer relationship Management), APO (Advanced Planner Optimiser), BW (Business Information Warehouse), SRM (supplier Relationship Management. 